Volume 19, No 3 International Journal of Radiation Research, July 2021

\title{
Background radiation levels in selected dumpsites in Nnewi community setting Southeast Nigeria
}

\author{
D.C. Ugwuanyi ${ }^{1}$, O.N. Nzotta ${ }^{1}$, M.P. Ogolodom ${ }^{*}$, T.F. Sibeudu ${ }^{2}$, \\ A.M. Ibekwe' ${ }^{2}$, N.O. Ezeaku' \\ ${ }^{1}$ Department of Medical Radiography and Radiological Sciences, Nnamdi Azikiwe University, Nnewi Campus, \\ Anambra State, Nigeria \\ ${ }^{2}$ Department of Nursing Sciences, Faculty of Health Sciences and Technology, Nnamdi Azikiwe University, Nnewi \\ Campus, Anambra State, Nigeria
}

\section{Short report}

\section{*Corresponding authors: \\ Michael P. Ogolodom, M.Sc.,} E-mail:

mpos2007@yahoo.com

Revised: October 2020

Accepted: October 2020

Int. J. Radiat. Res., July 2021; 19(3): 743-747

DOI: $10.29252 /$ ijrr.19.2.743

\begin{abstract}
Background: Nnewi town has undergone a marked increase in industrialization over the years. Considering the continuous disposal of automotive and hospital wastes in dumpsites within the town there is a need to ascertain the background radiation level of some of its dumpsites. Objective: To evaluate the level of background radiation in some selected dumpsites in Nnewi and compare the background radiation dose levels with the worldwide recommended average natural dose of $2.4 \mathrm{mSv} / \mathrm{yr}$ to humans. Methods: The levels of background radiation in these dumpsites were estimated using a well-calibrated International Medicom CRM-100 Digital Radiation Monitor (survey meter). A cross-sectional survey was adopted for this study. Following the standard procedure, the radiation monitor was held at a distance of 1.0 meters above the ground and three readings are taken at each location and the mean recorded. The Annual Absorbed Dose Rate (ADR), Absorbed Dose Rate (AD) and the Annual Equivalent Dose Rate (AEDR) were calculated. Descriptive statistics were used to summarize the data using Statistical Package for Social Sciences SPSS version 20. Results: The mean of the calculated Annual Absorbed Dose Rates recorded at 21 and 24 meters was marginally greater than the accepted exposure rate for the public with the values of $1.5 \mathrm{mSv} / \mathrm{year}$ respectively. At 12 and 27 meters, the values were $1.5 \mathrm{mSv} /$ year for Bank Road dumpsite respectively. Other distances were below the limit of $1 \mathrm{mSv} /$ year for the public and also below the dose limit of $20 \mathrm{mSv} / \mathrm{year}$ for radiation workers as recommended by the ICRP. Conclusion: The radiation levels emitted from the study area were within permissible limits for the general population. Therefore there is little risk of instantaneous radiation hazard with an estimated safety zone at 6 meters from the dumpsites.
\end{abstract}

Keywords: Absorbed dose, absorbed dose rate, annual absorbed dose rate, annual equivalent dose rate.

\section{INTRODUCTION}

Man is constantly exposed to ionizing radiation in his environment from natural sources such as radon which accounts for $80 \%$ and man-made sources primarily medical X-rays, accounting for $20 \%$, (1). The use of ionizing radiation in medical imaging for diagnostic and interventional purposes has risen dramatically in recent years with a concomitant increase in exposure of patients and health workers to radiation hazards. The documented harmful health effects following exposure to ionizing radiation over the past two decades $(2,3)$ 
and reported evidence of poor knowledge of radiation safety among various cadres of health workers and the public at risk of exposure compounded this unfortunate condition (4-6).

Background radiation describes the ionizing radiation present in the environment at a particular location which is not due to the deliberate introduction of radiation sources. The ambient radiation exposure to man includes the natural and artificial radioactivity in his environment (7) and the average annual effective dose from natural radiation is about 2.4 milli-Sieverts $(\mathrm{mSv})$, one third being due to external exposure and two thirds to internal exposure (8).

In recent years, many researchers have assessed the level of background radiation and its awareness in some cities and institutions in the different geopolitical zones of Nigeria and their findings also revealed that radiation is a common companion in the human environment as it occurs either naturally or through man's activities ${ }^{(9-12)}$. Hence, it is essential to study and ascertain the level of background radiation within the environment of man to help man adopt appropriate means for radiation protection and control and so prevent the harmful effects of ionizing radiation be it from the background or man-made sources. This study was designed to i) to determine the level of background radiation at some selected dumpsites in the Nnewi Community. ii) to compare background radiation dose levels in the selected dumpsites with the worldwide recommended average natural dose of $2.4 \mathrm{mSv} /$ yr to humans (8) and iii) to investigate the relationship with the variation of radiation levels with people's well-being and safety of individuals within the selected areas.

\section{MATERIALS AND METHODS}

A cross-sectional survey design was adopted for the study and was conducted at all the major dumpsites within Nnamdi Azikiwe University Teaching Hospital, and those close to the motorcycle spare parts market Nnewi, which are the major contributing factor to waste deposits of the hospital and automobile wastes within the community. These dumpsites were selected using a single-stage cluster sampling technique.

The background radiation levels at the selected dumpsites were obtained using a well-calibrated International Medicom CRM-100 Digital Radiation Monitor. The CRM-100 is a general-purpose Geiger counter that measures alpha, beta, gamma, and X-radiation. It has a liquid crystal display (LCD) screen that shows the current radiation level in users' choice; milli-roentgens per hour $\mathrm{mR} / \mathrm{hr}$, Counts per minute CPM, micro-sieverts per hour $\mu \mathrm{Sv} / \mathrm{hr}$, Counts per second CPS.

An in situ (in the normal location) background radiation measurement approach was adopted following standard procedure described by (13), in which the radiation monitor was held at a distance of 1.0 meters above the ground and the mean of (at least) three readings taken at each location was recorded. This radiation meter has a maximum response to environmental radiation during the hours of 1300 to 1600 (13), hence the readings were taken during this period for optimum results. The values of readings obtained for each dumpsite were presented in a table. For measuring mixed alpha, beta, and gamma radiation, the counts per minute CPM mode was used. The background radiation readings obtained in Counts per minute CPM were converted to $\mu \mathrm{Sv} / \mathrm{hr}$ using the relation; $10 \mathrm{CPM}=0.10 \mu \mathrm{Sv} / \mathrm{hr}$ that is $100 \mathrm{CPM}=1$ $\mu \mathrm{Sv} / \mathrm{hr}$ (CRM-100 Guide). The annual equivalent dose rate in $\mathrm{mSv} / \mathrm{yr}$ of the values was calculated using the recommended outdoor occupancy factors of 0.2 (14).

- To convert dose rate from $\mu \mathrm{Sv} / \mathrm{hr}$ to $\mathrm{mSv} / \mathrm{yr}$ for Outdoor;

- Dose rate per year $=\mathrm{X} \mu \mathrm{Sv} / \mathrm{hr} \times$ Total hours in a year $\times$ outdoor occupancy factor $(0.2)$.

- Based on 24 hours a day and 365 days in a year;

- The number of hours in a year will be $24 \times$ $365=8760$ hours.

- Hence; $\mathrm{X} \mu \mathrm{Sv} / \mathrm{hr} \times 8760 \times 0.2=$ Outdoor dose rate per year.

The obtained data were analyzed using statistical package for social sciences (SPSS version 20, SPSS Inc, Chicago IL, USA). Int. J. Radiat. Res., Vol. 19 No. 3, July 2021 
Descriptive statistic (mean, standard deviation) of various background radiation values was obtained.

\section{RESULTS}

Radiation exposure rates were obtained from 10 locations at increasing distances of three meters $(3 \mathrm{~m})$ in each of the locations. Three different measurements were obtained at each distance and the mean calculated. Calculated values of annual absorbed dose rate (AADR), absorbed dose rate (ADR), and annual equivalent dose rate (AEDR) are presented in tables 1 and 2 . The mean background radiation measured at the study site was $0.113 \mu \mathrm{Sv} / \mathrm{hr}$ and $0.108 \mu \mathrm{Sv} / \mathrm{hr}$ for the dumpsite in Nnamdi Azikiwe University teaching hospital (sites A) and dumpsite in Bank Road motorcycle spare parts Nnewi (Site B) respectively.

The mean exposure rates had an average value of $0.113 \pm 0.012 \mathrm{uSv} / \mathrm{hr}$ in site $\mathrm{A}$ and 0.08 to $0.12 \mu \mathrm{Sv} / \mathrm{hr}$ with an average value of $0.108 \pm 0.011 \mu \mathrm{Sv} / \mathrm{hr}$ in site B. The study area had an overall mean absorbed dose rate of $0.47 \mathrm{mSv} /$ yr for site $\mathrm{A}$ and $0.46 \mathrm{mSv} / \mathrm{yr}$ in site $\mathrm{B}$. The calculated outdoor AEDR ranged between $0.13 \mathrm{mSv} / \mathrm{yr}$ to $1.91 \mathrm{mSv} / \mathrm{yr}$ in site $\mathrm{A}$ and 0.17 $\mathrm{mSv} / \mathrm{yr}$ to $1.91 \mathrm{mSv} / \mathrm{yr}$ in site B.

Table 1. Radiation measurement in dumpsite in Nnamdi Azikiwe University Teaching Hospital, Nnewi, Anambra State.

\begin{tabular}{|c|c|c|c|c|}
\hline $\begin{array}{c}\text { Distances } \\
\text { (meters) }\end{array}$ & $\begin{array}{c}\text { Mean } \pm \text { SD } \\
(\mu \mathrm{Sv} / \mathrm{hr})\end{array}$ & $\begin{array}{c}* \text { ADR } \\
(\mathrm{mSv} / \text { year) }\end{array}$ & AD & $\begin{array}{c}* * \text { AEDR } \\
\text { Outdoor } \\
(\mathrm{mSv} / \text { year })\end{array}$ \\
\hline Control & $0.07 \pm 0.01$ & 0.12 & 0.00012 & 0.14 \\
\hline 3 & $0.13 \pm 0.01$ & 0.22 & 0.00022 & 0.26 \\
\hline 6 & $0.07 \pm 0.01$ & 0.12 & 0.00012 & 0.14 \\
\hline 9 & $0.10 \pm 0.01$ & 0.17 & 0.00017 & 0.20 \\
\hline 12 & $0.14 \pm 0.00$ & 0.24 & 0.00024 & 0.29 \\
\hline 15 & $0.15 \pm 0.02$ & 0.26 & 0.00026 & 0.13 \\
\hline 18 & $0.13 \pm 0.02$ & 0.22 & 0.00022 & 0.13 \\
\hline 21 & $0.09 \pm 0.01$ & 1.57 & 0.00157 & 0.26 \\
\hline 24 & $0.09 \pm 0.01$ & 1.57 & 0.00157 & 1.91 \\
\hline 27 & $0.11 \pm 0.02$ & 0.19 & 0.00019 & 0.23 \\
\hline 30 & $0.12 \pm 0.01$ & 0.21 & 0.00021 & 0.25 \\
\hline
\end{tabular}

${ }^{*} A D R=$ Annual absorbed dose

**AD = Absorbed dose rate

$* * * A E D R=$ Annual effective dose rate
Table 2. Radiation measurements of dumpsite in Bank Road motorcycle spare parts Nnewi, Anambra State.

\begin{tabular}{|c|c|c|c|c|}
\hline $\begin{array}{c}\text { Distances } \\
\text { (Meters) }\end{array}$ & $\begin{array}{c}\text { Mean } \pm \text { SD } \\
(\mu \mathrm{Sv} / \mathrm{hr})\end{array}$ & $\begin{array}{c}* \text { ADR } \\
(\mathrm{mSv} / \text { year })\end{array}$ & $* *$ AD & $\begin{array}{c}* * * \text { AEDR } \\
\text { Outdoor } \\
(\mathrm{mSv} / \text { year }\end{array}$ \\
\hline Control & $0.09 \pm 0.01$ & 1.57 & 0.00157 & 1.91 \\
\hline 3 & $0.11 \pm 0.01$ & 0.19 & 0.00019 & 0.23 \\
\hline 6 & $0.11 \pm 0.02$ & 0.19 & 0.00019 & 0.23 \\
\hline 9 & $0.08 \pm 0.01$ & 0.14 & 0.00014 & 0.17 \\
\hline 12 & $0.09 \pm 0.01$ & 1.57 & 0.00157 & 1.91 \\
\hline 15 & $0.11 \pm 0.01$ & 0.19 & 0.00019 & 0.23 \\
\hline 18 & $0.13 \pm 0.01$ & 0.22 & 0.00022 & 0.26 \\
\hline 21 & $0.14 \pm 0.01$ & 0.24 & 0.00024 & 0.29 \\
\hline 24 & $0.10 \pm 0.01$ & 0.17 & 0.00017 & 0.20 \\
\hline 27 & $0.09 \pm 0.01$ & 1.57 & 0.00157 & 1.91 \\
\hline 30 & $0.12 \pm 0.01$ & 0.21 & 0.00021 & 0.25 \\
\hline
\end{tabular}

${ }^{*} \mathrm{ADR}=$ Annual absorbed dose

**AD = Absorbed dose rate

***AEDR $=$ Annual effective dose rate

\section{DISCUSSION}

This study was intended to ascertain the contribution of the wastes in some selected dumpsites in the Nnewi community setting to the exposure levels to both humans and the immediate environment and to compare its value to internationally acceptable dose limits. It is known that the levels of radiation especially of the gamma type are directly associated with the activity of concentration of radionuclides in materials found at dumpsites (15). On physical inspection, wastes found in the study area include hospital waste such as syringes, bandages, tissue paper, cotton wool, plastic, motorcycle tires, paper products, metal scraps, electronics, and some food remains. The putrefying process that these items undergo could have been responsible for the radiation values recorded at the dumpsites. The values as presented in both tables showed that the exposures were highest within 21 meters and 24 metres in site A, and 12 meters and 27 meters in site B. This means that the general public doing business within these areas is at greater risk of radiation hazards although, convention radiation intensities decrease with increasing distance. This is in line with a study carried out by (16) who recorded that there was an inverse relationship of the exposure and absorbed dose 
rate as the distance from the dumpsite increased.

The mean exposure rate, the calculated annual absorbed dose rate, and annual effective dose rate were all below the generally accepted exposure limits of $2.4 \mathrm{mSv} /$ year of naturally occurring radiation as recommended by ICRP (17). The mean of the calculated annual absorbed dose rates recorded at the following distances of 21 meters and 24 meters from the dumpsite were noted to be marginally greater than the accepted exposure rate for the public with the values of $1.5 \mathrm{mSv} /$ year respectively for site $\mathrm{A}$ and at 12 meters and 27 meters also with the values of $1.5 \mathrm{mSv} /$ year for site B while the other distances were below the limit of $1 \mathrm{mSv} /$ year for the public and also below the dose limit of $20 \mathrm{mSv} /$ year for radiation workers as recommended by the ICRP (17). This could owe to the fact that more hazardous materials like chemical waste which may contain more radionuclides are not contained in the waste.

The radiation readings taken at the study site were within permissible limits. Radiation levels were highest at 21 meters and 24 meters for site A and also 12 meters and 27 meters for site B with values of $1.5 \mathrm{mSv} /$ year. Therefore individuals within these areas are at risk of higher radiation exposure than other distances. Patients, health workers, and pedestrians are not in danger of immediate radiation effects or hazards from the measurements at the dumpsites within the teaching hospital. Unavailability of an open control area devoid of possible contributing factors to background radiation such as houses and equipment is the major limitation of this study.

\section{CONCLUSION}

The radiation levels emitted from the study area are within permissible limits for the general population. This study has been able to reveal the estimated radiation level around the study sites, which is an indication of the level of radiation hazards faced and also provide baseline dumpsite radiation level data for further research in the community.
Conflicts of interest: Declared none.

\section{REFERENCES}

1. Hendry JH, Simon SL, Wojcik A, Sohrabi M, Burkart W, Cardis E, et al. (2009) Human exposure to high natural background radiation: what can it teach us about radiation risks? J Radiol Prot, 29(0): A 29-A42.

2. ICRP 60 (1990) Recommendations of the international commission on radiological protection. Ann ICRP, 21: 1-3.

3. IBSS Safety Series (1996) International Atomic Energy Agency 1996. International basic safety standards for protection against ionizing radiation. Vol 115.

4. BEIR VII (2006) Biological Effects of Ionizing Radiation (BEIR) VII Report. Health risks from exposure to low levels of ionizing radiation. The National Academies Press, Washington, DC, 2006.

5. Tubiana $M$, Aurengo $A$, Averbeck $D$, Bonnin $D$, LeGuen $B$, Masse R, Monier R, Valleron AJ, de Vathaire F (2005) Dose -effect relationships and estimation of the carcinogenic effects of low doses of ionizing radiation. Académie Nationale de Médecine. Paris: Institut de France-Académie des Sciences. What is this a paper or book Provide details in proper format for journal or book.

6. Cullen TL and France EP (1975) Provide Paper Title??? .Proc IntSymp Poços de Caldas Academia Brasileria de Ciencias Rio de Janeiro; 1977. Int. Symp. On Areas of High Natural Radioactivity. Why the date of presentation and proceeding is different. Where the congress was held? Please provide references accurately.

7. Centre for Disease Control and Prevention, CDCP (2014) Radiation and your health. Available at http:// www.cdc.gov/nceh/radiation/decay.htm. Accessed 14th December 2019.

8. National Council on Radiation Protection and Measurements, NCRP (2019) lonizing radiation exposure of the population of the United States. NCRP Report No: 160. Available at http://www.ncrponline.org/publication/ press.release/160press.html. Accessed 14th December 2019.

9. Farai IP and Vincent UE (2006) Outdoor radiation level measurement in Abeokuta Nigeria by thermos-luminescent dosimetry. Nigeria Journal of Physics, 18(1): 121-126.

10. Okoye PC and Avwiri GO (2013) Evaluation of background ionizing radiation levels of Braithwaite Memorial Specialist Hospital Port Harcourt, Rivers State. American J Sci and Industry Res, 4(4): 359-365.

11. Ramli TA, Aliyu AS, Agba EH, Saleh MA (2014) Effective dose from natural background radiation in Keffi and Akwanga towns, Central Nigeria. Int J Radiat Res, 12(1):4752.

12. Abubakar A, Sadiq AA, Musa MG, Hassan J, Malgwi DF (2017) Assessment of indoor ionizing radiation profile in radiology department FMC Asaba Delta State Nigeria. International Organization of Scientific Research (IOSR) Journal of Dental and Medical Sciences, 16(1): 98-101.

Int. J. Radiat. Res., Vol. 19 No. 3, July 2021 
13. Ebong IDU and Alagoa KD (1992) Fertilizer impact on ionization radiation background at a production plant. Nigeria Journal of Physics, 4: 143-149.

14. United Nations Scientific Committee on Effects of Atomic Radiation, UNSCEAR (2000) Sources and effects of ionizing radiation. Report to General Assembly. Annex B New York. Available at http://:www.unscear.org/unscear/en/ publications/2000. Accessed 23 December 2019.

15. Taskin HM, Karavus P, Ay A, Touzogh S, Hindiroglu G, Karaham $G$ (2009) Radionuclide concentration in soil and life- time cancer risk due to the gamma radioactivity in Kirklareli, Turkey. Journal of Environmental Radioactivity, 100: 49-5.

16. Olubosede O, Akinagbe OB, Adekoya O (2012) Assessment of radiation emission from waste dumpsites in the Lagos state of Nigeria. International Journal of Computational Engineering Research, 2(3): 806-811.

17. ICRP (1990) Recommendations for radiological protection. International Commission for Radiological Protection, Annals of ICRP 46: 194. 
